\title{
thebmj
}

Personal Views Personal views

\section{The second gasoline war and how we can prevent the third}

BMJ 2003; 326 doi: http://dx.doi.org/10.1136/bmj.326.7381.171 (Published 18 January 2003) Cite this as: BMJ 2003;326:171

Ian Roberts (ian.roberts@LSHTM.ac.uk), professor of public health London School of Hygiene and Tropical Medicine

War in Iraq is inevitable. That there would be war was decided by north American planners in the mid1920s. That it would be in Iraq was decided much more recently. The architects of this war were not military planners but town planners. War is inevitable not because of weapons of mass destruction as claimed by the political right, nor Western imperialism as claimed by the left. The cause of this war, and probably the one that will follow, is car dependence.

The United States has paved itself into a corner. The physical and economic infrastructure of the United States is so highly car dependent that it is pathologically addicted to oil. Without billions of barrels of precious black sludge being pumped into the veins of the US economy every year, the nation would experience painful and damaging withdrawal.

\section{The United States has paved itself into a corner}

The first Model T Ford rolled off the assembly line in 1908 and was a miracle of mass production. In the first decade of the new century, car registrations in the United States increased from 8000 to almost 500 000. Within the cities buses replaced trams, and then cars replaced buses. In 1932 General Motors bought and then closed down the tram system. But it was the urban planners who really got America hooked. Car ownership offered the possibility of escape from dirty crowded cities to leafy garden suburbs and the urban planners provided the escape routes.

Throughout the 1920s and 1930s, America "road built" itself into a nation of home owning suburbanites. Public transport rallied temporarily during the second world war, when car makers switched to making munitions and petrol rationing was introduced, but for the last time. At the end of the war, energy conservation turned to consumption. Cities like Los Angeles, Dallas, and Phoenix were moulded by the private passenger car into vast urban sprawls with such widely dispersed markets that it is now almost impossible to service them economically with public transport.

As the cities sprawled, the motor manufacturing industry consolidated. Car making is now the main industrial employer in the world, dominated by five major groups of which General Motors is the largest. The car makers forged both the livelihood and landscape of north Americans.

Motor vehicles are responsible for about a third of global oil use but for more than half of oil use in the 
United States (www.wri.org/wri/climate). In the rest of the world, heating and power generation account for most oil use. The large increase in oil prices during the 1973 Arab oil embargo encouraged the substitution of oil with other fuels in heating and power generation, but in the transport sector there is little scope for oil substitution in the short term. Because of artificially low oil and gasoline prices that did not reflect the true social costs of their production and use, there was little incentive to seek alternative energy sources in the transport sector. US transport is now almost totally dependent on oil and supplies are running out.

Suburban America needs oil and Saddam Hussein is sitting on it. The US economy needs oil like a junkie needs heroin and Iraq has 112 billion barrels, the largest supply in the world outside Saudi Arabia. Even before the first shot has been fired, there have been discussions about how Iraq's oil reserves will be carved up. All five permanent members of the United Nations Security Council have international oil companies that have an interest in regime change in Baghdad.

Car dependence is a global public health issue of which gasoline wars are only one facet. Every day about 3000 people die and 30000 people are seriously injured on the world's roads in traffic crashes. More than $85 \%$ of the deaths are in low and middle income countries, with pedestrians, cyclists, and bus passengers bearing most of the burden. Most of the victims will never own a car, and many are children. That we accept this carnage as the collateral damage in a car based transport system indicates the strength and pervasiveness of car dependency.

Car use and the corresponding decline in physical activity is an important cause of the obesity epidemic in the United States and the United Kingdom, and physical inactivity increases the risks of heart disease, diabetes, osteoporosis, and hypertension (BMJ 1998;316:242-3). Car based shopping has turned many small towns into ghost towns and has severed the supportive social networks of community interaction.

The first gasoline war was waged in Kuwait and the second will be waged in Iraq. The world must act now to prevent the third. We must reclaim the streets, promote walking and cycling, strengthen public transport, oppose new road construction, and pay the full social cost of car use. We must advocate for land use policies that reduce the need for car travel. We need "urban villages" clustered around public transport nodes, not sprawling car dependent conurbations. We can all play our part and we must act now. 